\title{
GREEN SUPPLY CHAIN PRACTICES FRAMEWORK FOR PETROCHEMICALS IN EGYPT
}

\author{
Karim Soliman, Ghada ElKady \\ Arab Academy for Science, Technology \& Maritime Transport, Egypt, \\ Karim.mohamed@aast.edu, ghada-elkady@aast.edu
}

\begin{abstract}
The aim of this study is to determine the extent of green supply chain management (GSCM) practices used by Shell and Co-operation (Co-op) Petroleum Companies in Egypt and to evaluate the effect of GSCM practices on the operational performance of both companies. A conceptual framework was developed to link the GSCM practices and operational performance. The framework consisted of three GSCM practices (green procurement, green manufacturing, and reverse logistics) as independent variables and four operational attributes (quality, safety, delivery, and flexibility) as dependent variables. The data were collected through on-site surveys, using eighteen-item-questionnaire with the relevant departments in both companies from the three managerial levels (i.e. strategic, tactical, and operational). Further, the results, based on benchmarking, were statistically analyzed by Fischer analysis. The results offer guidelines to petroleum and lubricant manufacturers to enhance their operational performance and customer satisfaction while employing GSCM practices throughout their entire supply chain (SC).
\end{abstract}

Keywords - green supply chain management, operational performance, reverse logistics, green procurement, green manufacturing.

\section{INTRODUCTION}

The increase in greenhouse gas emissions, global warming and environmental pollution by companies has increased the need for organizations to reorganize their SC processes to improve the operational performance of enterprises and thus products in accordance with the requirements of environmental regulations [1]). Furthermore, environmental pollution and the increase in greenhouse emissions have led to an increased demand for organizations to reorganize SC operations, thereby conserving scarce resources. The GSCM is an important organizational philosophy to achieve corporate profit and market share objectives by reducing environmental risks and impacts while improving the ecological efficiency of these organizations and their partners [2]. As a synergistic joining of environmental and supply chain management (SCM), the competitive and global dimensions of these two topics cannot go unnoticed by organizations. Likewise, the rise in environmental missions and concerns lead to the need to reduce environmental pollution resulting from industrial development with SCM [3]). Moreover, Monshiwa [4] acknowledged that any competitive advantage obtained or can be obtained by applying the green approach and accordingly, this creates pressure on companies not to ignore these green initiatives.

With the increase in environmental concerns during the past decade, a consensus is growing that environmental degradation issues accompanying industrial development should be addressed together with SCM, thereby contributing to GSCM [5]).

Egypt is one of the developing countries in the world and is becoming increasingly industrialized and this makes Egypt faces a heavy burden on the environment. Likewise, multinational organizations and developed countries use the developing countries as a point of disposal of endemic products and this has environmental impact [6]. For this reason, this research attempts to answer the following questions: (1) What are the current state of GSCM practices adoption by Shell and Co-op petroleum companies in Egypt? (2) How have the GSCM practices affected the operational performance at Shell and Co-op petroleum companies? And (3) What are the drivers of GSCM practices in Shell and Co-op petroleum companies?

Hence, this research will help local companies operating in the lubricant industry, such as Co-op petroleum company, to be more involved in 
implementing the GSCM concept. Additionally, the management will be able to identify GSCM practices that will develop and improve the operational performance of the Co-op company besides all local companies operating in this controversial area. Besides, how these companies can benefit from the implementation of Shell's GSCM practices and their effective impact on their operational performance. It has been noted that previous studies on the evaluation of operational performance and the effect of implementing GSCP in this field are few, especially in developing countries, such as Egypt. Thus, this research is urgently needed to determine how the operational performance of companies in the lubricant industry is affected by the implementation of GSCM practices.

The remainder of the paper is organized as follows. In Section 2, the literature is briefly discussed. In Section 3 , the methodology section is introduced. Then in Section 4, the analysis and findings are presented. Finally, Sections 5 and 6 conclude the study, including the theoretical contributions and managerial implications of the findings.

\section{LITERATURE REVIEW}

Environmentally sustainable GSCM has emerged as organizational philosophy to achieve corporate profit and market share objectives by reducing environmental risks and impacts while improving the ecological efficiency of these organizations and their partners [7];[2]. Likewise, it is necessary to integrate the organizational environmental management practices into the entire $S C$ to achieve a sustainable SC and maintain a competitive advantage [8]; [9]. The GSCM practices should cover all the SC activities, from green purchasing to integrate lifecycle management, through to manufacturer, customer, and closing the loop with reverse logistics [10]. Thus, the literature review section presents an overview on all the previously mentioned concepts and thoughts and is divided into two main sections: GSCM concepts and paradigms, and the GSCM practices and operational performance, all discussed respectively.

\section{Green Supply Chain Management Practices}

The full concept of GSCM was first proposed by the Michigan State University Manufacturing Research Association (MRC) in 1996 to comprehensively consider environmental impacts and improve the resources of manufacturing chains (Handfield, 1996). This means that it aims to reduce the environmental impacts of products at the end of use by tracking and controlling purchases of raw materials, in order to ensure compliance with environmental rules and regulations. Furthermore, awareness of environmental pollution has increased among people around the world, making them curious about protecting the environment. As a result, people are planning to buy green products, and the concept of GSCM is becoming more popular and gradually became the new concept of sustainable development of enterprises.

The first series of green SCs emerged in the context of 1989 when [1] first published how to develop an ideal forecasting system for organizations to predict reusable products, and the first book of green design literature came into context in 1991. Later, the article, published by [11] was the first to examine the need for green design to reduce the impact of waste products. While [2] came to context and expanded the green design framework. According to Beamon [12] , wastes from industrialization and the use of natural resources contribute to environmental pollution. In addition, scarcity of resources is another factor that enterprises and industrial companies must study. Therefore, the GSCM is the only way to deal with these environmental problems because GSCM has its primary role in dealing with environmental degradation, for example, the contraction of raw material resources, the lack of scientific and professional treatment with waste, and the increasing level of pollution [13].

The GSCM practices is frequently used for various activities implemented by any company to diminish the negative impacts on the environment [14]. These activities vary from green purchasing to integrated SCs flowing from suppliers to the manufacturer, to customers and reverse to logistics, which is named as "closing the loop" [8] as shown in Figure 1.

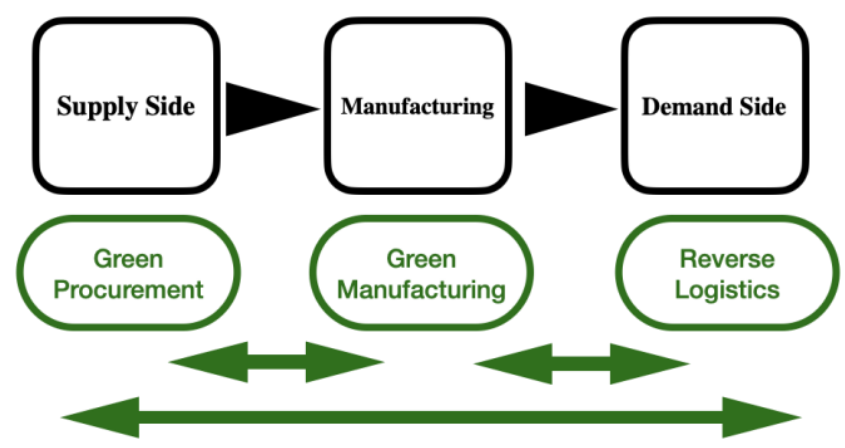

Fig .1 The areas of literature associated with GRSC Source: Zhu and Sakris, 2006. [8]

When empirical studies on GSCM are assessed, it has been found that there are several GSCM dimensions 
discussed by different researchers, such as green purchasing, green manufacturing, green logistics, green packaging, green marketing, green building, green education, investment recover, eco-design, etc.
[15]; [8]; [16]; [17]; [18]. In light of this researches, three dimensions were selected to be included in this study as shown in Table 1 and further will be briefly described in the next sub-sections.

Table 1. GSCM DIMENSIONS.

\begin{tabular}{|c|l|l|}
\hline Dimension & \multicolumn{1}{|c|}{ Definition } & Author(s) \\
\hline Green Purchasing & $\begin{array}{l}\text { The integration of environmental efforts, purchasing activities and } \\
\text { environmental objectives of the firm }\end{array}$ & $\begin{array}{l}\text { Foo [19] et al., 2019; Zhang } \\
{[20] \text { et al., 2018 }}\end{array}$ \\
\hline Green Manufacturing & $\begin{array}{l}\text { The planning and implementation of energy-saving resources in the } \\
\text { production process to produce environmentally friendly products with the } \\
\text { least resources }\end{array}$ & $\begin{array}{l}\text { Ma et al., 2018 [21]; Karimi } \\
\text { et al., 2019 [22] }\end{array}$ \\
\hline Reverse Logistics & $\begin{array}{l}\text { Managing how products and/or materials are returned to the original } \\
\text { manufacturer or agent for reuse, recycling or re-manufacture. }\end{array}$ & $\begin{array}{l}\text { Bottani et al., 2019 [10]; Bai } \\
\text { and Sakris, 2019 [23] }\end{array}$ \\
\hline
\end{tabular}

\section{A. Green purchasing}

The green purchasing implicates a company evaluating the environmental performance of their vendors, which requires these vendors to implement all necessary operation measures to ensure the environmental quality [7]. Furthermore, this step is considered to be the first step in the value chain that positively affect the operational performance of the entire chain [24]. [18] acknowledged that green purchasing entails all organizations in the entire chain to get attention towards the eco-labeling of all purchased items, supplier's cooperation to attain the environmental objectives, supplier's environmental audit, supplier's International Standards Organization (ISO) 14000 accreditation, supplier's environmentally friendly practice assessment, and finally, providing the required environmental design specification to the suppliers. Chen [25] also points out that green procurement has beneficial effects on the corporate pollution control system and can promote the successful implementation of the company's quality and environmental standards. Likewise, [24] signified that green purchasing involves a procurement function through various SC activities, such as life cycle analysis (LCA) and 3R model - reduction, reuse, and recycling that belong to the product design and process part. The first is to reduce waste received from products and to guide consumers to reduce their waste by purchasing their own needs only and purchasing goods made from recyclable materials rather than nonrecyclable materials. The second $R$ is to reuse any wastes to reduce environmental pollution and global warming. Finally, the third $\mathrm{R}$ is to recycle the disposed waste by segregating the materials from each other.

\section{B. Green manufacturing}

The green manufacturing is considered the significant step in all GSCM activities in any industry to continuously improve their operational performance such as reducing cost, the quality of the products, and the environmental risks, all of which bring a competitive advantage to the product [22]. Sezen [26] affirmed that pollution can be reduced or mitigated through continuous improvement strategies that focus on green design and manufacturing. Nevertheless, Dubey [27] added that green manufacturing is a system that connects all problems associated with the design, planning, and manufacturing matters efficiently to control the emerged waste amounts to be consistent with the environmental standards and procedures.

\section{Reverse logistics}

As reverse logistics is gaining increasing interest and relevance, the question becomes whether it is enough to limit greening efforts to one segment of the SC and single companies or choosing to expand these efforts to the entire chain. Greening can start right at the source with supply conditions and can work its way through storage and packaging practices to distribution and end-consumers [28]. However, the reversed flow can take different forms, from collection to return shipments into the distribution channel, followed by disassembly and re-use of selected parts. Alternatively, used goods could be shredded and scrapped and reentered into production as raw materials. Returned goods, or elements of the product, could even be returned to suppliers and supply chain partners for them to re-manufacture [23]. Those possible SC applications should be taken into consideration. One step further, dis-assembly operations in the reversed 
flow might call for a proactive design for dis-assembly right in the initial product design stage of both supplier and customer [10].

Of all green activities, it is relatively easier to repair existing products and run renovations. More and more companies pay attention to yield management or product recovery management. Reverse logistics aims to ensure the return of materials and products from the user to the product for reuse, recycling, and regeneration [29]. However, for most companies, they do not put reverse logistics in their planning strategies initially, although they will take action to respond to the requirements of customers or members of the final channel.

\section{The Relationship between GSCM Practices and Operational Performance}

There are several impacts of GSCM practices on performance outcomes. Generally, the adoption of GSCM practices by manufacturing organizations lead to improved environmental performance and economic performance, and on operational performance [18]. Laws, procedures, standards, and incentives regulated by regulatory institutions make corporate responsibility more environmentally friendly [30]. Sarkis [31] discussed the impact of persistent pressures through laws and regulations on improving awareness in developed countries such as the United States of America where large industrial companies often face scrutiny by environmental activists [7]. Thus, companies and organizations are under pressure from their competitors, forcing companies to implement green supply chain practices to reduce competition and make them competitive [32] . Additionally, consumers are increasingly aware of the environmental impacts, which leads to the selection of the goods they receive and ask companies to apply the minimum green standards in their product design and thus to preserve the environment [33]. Companies take societal responsibilities into society as companies believe they must commit themselves to society to conform to expectations and standards that lead to accepted business behaviors [34]. Thus, implementation of GSCM practices can result in a set of advantages for the company itself, for procurement and supply, and for the community itself.

Green procurement and supply can be improved to the extent that green supply facilitates information exchange and flow and cooperative relationships in the supply chain [35]; [36]. The benefits of green supply to society begin with a green environment, reduce hazardous and harmful substances, use scarce resources more efficiently, and avoid waste. Green supply also helps to spread environmental knowledge through green marketing and best practices. Environmental initiatives in the industrial supply chain should focus on the production and processing processes used by the supplier [37].

According to [33], the operational performance was summarized in four factors:

- Quality: Evaluate the product or service that meets customer satisfaction and expectations.

- Safety: Evaluate both the health and the working environment of the staff.

- Delivery: Evaluate the business unit with its achievement in a proper time based on customer requirement.

- Flexibility: This means that this requires a great deal of flexibility in different processes, such as reducing the number of back orders, lost sales, and late orders.

Additionally, [5] indicated the positive relationship between the GSC and multi-operational performances in cost, delivery, quality, and flexibility. While [38] signified the impact of customers' involvement in green practices on improving the customer satisfaction. Additionally, [39] affirmed that the GSCM practices lead to significant operational performance increase in terms of quality, cost, and flexibility, however, it does not have any impact on the delivery aspect. Accordingly, for this study, Figure 2 presents the initial conceptual framework to link the three GSCM practices previously identified and the four operational performance attributes adopted by [33].

\section{METHODOLOGY}

Benchmarking is an assessment process on best performing corporate goods, services and procedures [40]. Benchmarking concept is also associated with individual corporations' attempts to recognize and emulate best practices in their own industry. Moreover, benchmarking has also been cited as an effective method to constantly enhance organizational performance, overall management of quality and competitive advantage [2]; [41].

Benchmarking as a mechanism to identify operating performance measures and compares SCs in relation 
to selected measures. Accordingly, this study used descriptive research design by using benchmarking between Shell and Co-op companies in Egypt. In this study, descriptive research design based on two types of benchmarking; best-in-class and operational benchmarking. In order to achieve this aim, both approaches were used to explain the relationship between the GSCM practices and operational performance by benchmarking the factors that influence the impact of effective GSCM between Shell and Co-op companies in Egypt. The performance measurement methodology is defined as an effective tool for managing change; it can be described as an ongoing process to identify, understand and evaluate industry best practices to improve the performance of an organization [42]. This is usually done by studying other organizations that carry out similar operations [43]. In contrast, performance measurement is an external activity that can enable the organization to move away from tradition. However, standard measurement and comparative analysis should not be confused. In the comparative comparison group, the metrics for similar elements are compared between organizations or within the organization, and this is simply one step in the normative assessment process [44].

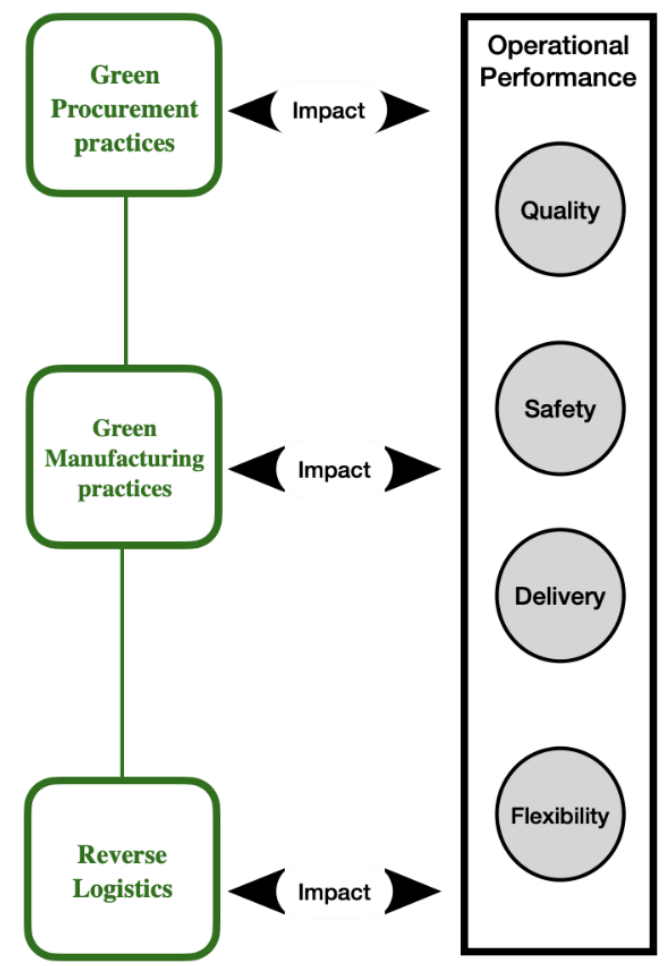

Fig .2 Initial Conceptual framework to link GSCM practices and operational performance

Source: developed by the authors

Shell and Co-op companies have been chosen for the purpose of this study as one of them is a multinational company operating in Egypt (i.e. Shell), and the other was a local Egyptian company (i.e. Co-op). The reason behind that is to drill down into performance gaps to recognize areas for improvement [42]. Figure 3 presents the overall research design.

\section{Data Collection}

This study focuses on the relationship between GSCM practices, and the SC operational performance. The target sample was managers in both companies from the three managerial levels (i.e. strategic, tactical, and operational). Accordingly, the targeted departments were procurement, production, marketing, quality assurance, and logistics departments. There was an intention to engage a larger sample, however, if a large sample is used, data may become repetitive [45]. Owing to the nature of this benchmarking study, saturation was not applied on less than 25 face-to-face conducted questionnaires. The data collection was conducted in person for four months from August 2019 to November 2019. Ethical issues have been considered through gaining well-versed consent and making confirmation that the data will be treated as confidential to be used only for research purpose. All surveys were conducted on-site, using an eighteenitem- questionnaire for collecting data and were guided by the objectives of the study. The questionnaire scale was in the range from - to ++++ where respondents required to indicate their views on this scale. This scale was chosen by the researcher because it allowed the respondents to express their views more clearly and openly.

At the beginning, the survey questions were assessed by five professors from the SC management field. Then a pilot test was conducted with seven SC management consultants and industry experts. Minor modifications were received from the experts. However, most of the remarks were related to the wording of the questions, so they were re-written to be easily understood. The questionnaire consisted of two sections: section I; included, practices of GSCM, and section II; the operational performance with regards to implementation of GSCM practices.

\section{Data analysis}

Researchers are indeed concerned in recognizing significant cells relationships following a statistically valid chi-squared test [46]. Two test statistics are widely used to test the value of each cell. The first test is a 
standardized residual that is measured as a raw residual divided by a square root of the expected value, where the raw residual is defined. The discrepancy between the observed value and the predicted value. The second test shall be modified residual: raw residual divided by its standard error. Both experiments adopt the normal standard distribution asymptotically.

In this study, statistical analysis was performed using a statistical program (GMP for Windows version 5.1, SAS Institute, Cary, NC, USA). For data analysis, use the Fisher's exact test to compare Shell and the Co-op company to GSC; green procurement, green manufacturing, reverse logistics and operational performance; quality, safety, delivery and, flexibility. Data were analyzed as $-=0,+=25,++=50,+++=$ $75,++++=100$. At the end, the results were considered significant at $P<0.05$ which is considered acceptable to achieve the objectives of the study. The reason behind using Fisher's exact test in data analysis is that in case of small samples, the Fisher Exact test is considered an effective tool used instead of the chi square test for 2 in 2 tables.

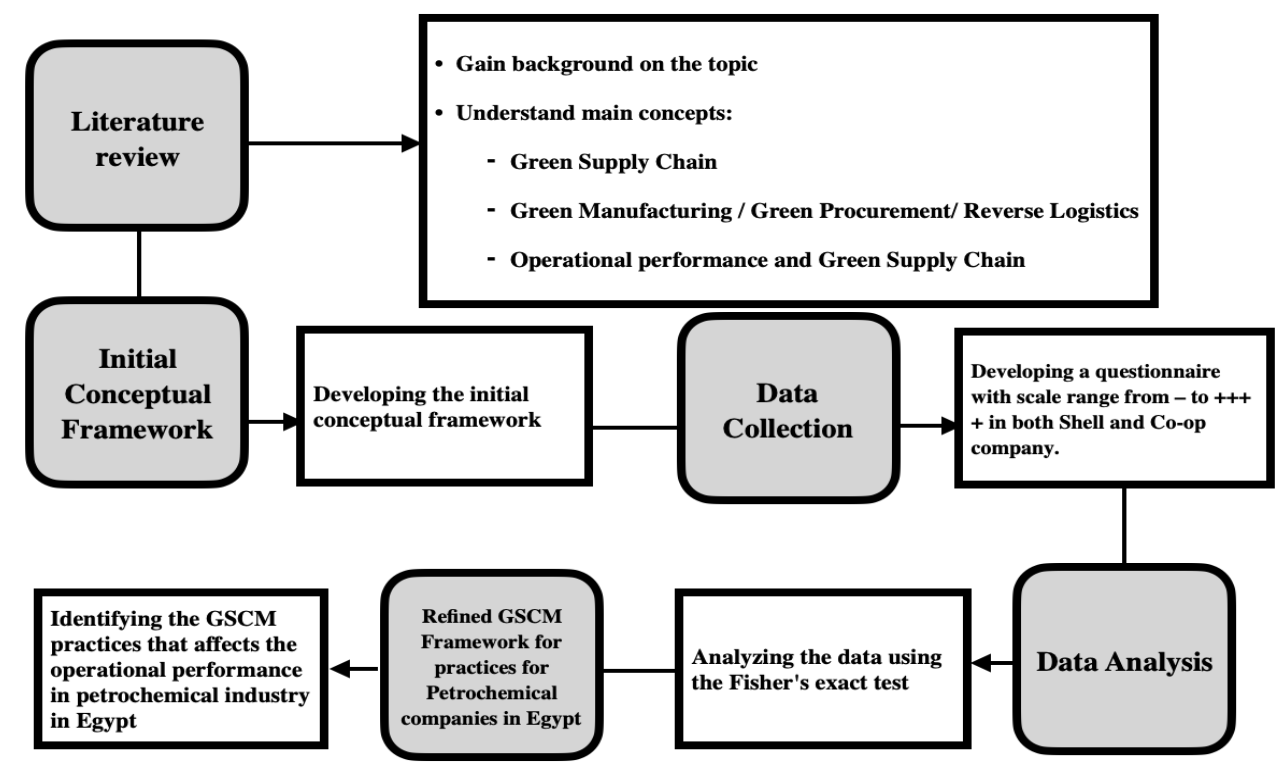

Fig. 3. Overall research design

Source: developed by the authors.

\section{ANALYSIS AND FINDINGS}

This study was carried out to determine the effect of green supply chain practices on operational performance of benchmarking study between Shell Egypt and Co-op Petroleum Company working in the lubricant industry. The study had two objectives. The first is to determine the extent of GSCM practices used by Shell and Co-op Petroleum Company in Egypt; the second objective is to establish the relationship between green supply chain management practices and operational performance of Shell and the Co-op Petroleum Company in Egypt. Accordingly, in the subsequent sections, the detailed descriptive analysis of the questionnaires conducted was analyzed using Fisher's exact test.

\section{Green Procurement}

The results of extent the firm practice green procurement are demonstrated in Table 2. The results showed that suppliers are required to have ISO 14001, Shell Company had significantly higher extent the firm practice green procurement than the Co-op company $(p<0.0001)$. Likewise, for purchasing materials that contain green attributes, the results revealed that Shell Company had significantly higher extent firm practice Green Procurement than the Coop Company $(p<0.00001)$.

Furthermore, the Fisher's exact test results unveiled that evaluate suppliers on specific environmental criteria, Shell Company has significantly higher extent the firm practice green procurement than the Co-op company $(p<0.0001)$. Likewise, the results showed that procure products that are made using recycled packages, Shell Company had a significantly higher extent the firm practice Green Procurement than the Co-op company $(p<0.0001)$. 
The SC network starts in Shell Egypt with the suppliers who are mainly raw material suppliers (base oil and additives) and packaging materials. Suppliers are evaluated based on their commitment to environmental standards according to the Rider Center for SC Management (2008) that protects the environment from all aspects (as mentioned earlier). Base oils are supplied to the plant by refineries either inside or outside of Egypt. Additives are delivered to the Lubricant Oil Blending Plant (LOBP) through Alexandria port from Europe. All packaging material supply is locally supplied to the plant. These raw and packaging materials are used to manufacture a wide range of portfolio of products. Once products are produced, they are shipped to the distribution center in 6th of October waiting its turn to be shipped to the customers. Thus, the results revealed that Co-op company was not committed to environmental standards according to the regulations that protects the environment from all aspects.

Table 2. THE EXTENT AT WHICH THE FIRM PRACTICES GREEN PROCUREMENT.

\begin{tabular}{|l|c|c|}
\hline Green Procurement practices & Shell & Co-op \\
\hline Requiring suppliers to have ISO 14001 & $75^{* * *}$ & 25 \\
\hline $\begin{array}{l}\text { Purchasing materials that contain green } \\
\text { attributes }\end{array}$ & $75^{* * *}$ & 0 \\
\hline $\begin{array}{l}\text { Evaluating suppliers on specific } \\
\text { environmental criteria }\end{array}$ & $75^{* * *}$ & 0 \\
\hline $\begin{array}{l}\text { Procuring products that are made using } \\
\text { recycled packages }\end{array}$ & $75^{* * *}$ & 0 \\
\hline
\end{tabular}

Source: Research Data (2019) by using Fisher's exact tes.

Table 3. EXTENT AT WHICH THE FIRM PRACTICES GREEN MANUFACTURING.

\begin{tabular}{|l|c|c|}
\hline Green Manufacturing Practices & Shell & Co-op \\
\hline $\begin{array}{l}\text { Producing products that have packages } \\
\text { which can be recycled }\end{array}$ & $75^{\star * *}$ & 25 \\
\hline $\begin{array}{l}\text { Using life cycle assessment to evaluate } \\
\text { environmental load }\end{array}$ & 75 & 75 \\
\hline $\begin{array}{l}\text { Replacing hazardous substances with } \\
\text { that which are environmentally friendly }\end{array}$ & $66^{\star * *}$ & 33 \\
\hline $\begin{array}{l}\text { Minimizing the use of materials in } \\
\text { packaging }\end{array}$ & $75^{\star * *}$ & 0 \\
\hline $\begin{array}{l}\text { Encouraging reuse of products and } \\
\text { recycled materials }\end{array}$ & $75^{\star * *}$ & 25 \\
\hline $\begin{array}{l}\text { Reducing the size of packaging } \\
\text { Cooperating with suppliers to } \\
\text { standardize packaging }\end{array}$ & $75^{\star * *}$ & 0 \\
\hline
\end{tabular}

Source: Research Data (2019) by using Fisher's exact test.

\section{Green Manufacturing}

Results of the extent at which the firm practices green manufacturing are shown in Table 3. The Fisher's exact test results revealed that produce products that have packages which can be recycled, Shell company has significantly higher extent the firm practice of green manufacturing than the Co-op company $(p<0.0001)$. Likewise, the result of using life cycle assessment to evaluate environmental load showed non-significant difference between both companies. Furthermore, the results of replacing hazardous substances which are environmentally friendly showed that Shell company has significantly higher extent to which the firm practices green manufacturing than the Co-op company $(p<0.0001)$. Moreover, concerning the minimization of the use of materials in packaging, it was clear that Shell company had a significantly higher extent at which the firm practices green manufacturing than the Co-op company $(p<$ 0.0001). On the other hand, Shell Company has significantly higher extent at which the firm practices green manufacturing than the Co-operation Company $(p<0.0001)$ in encouraging the reuse of products and recycled materials. Likewise, concerning reducing the size of packaging, it was found that Shell Company had significantly higher extent at which the firm practices green manufacturing than the Co-operation Company $(p<0.0001)$. Finally, the results indicated that Shell company has significantly higher extent at which the firm practices green manufacturing than the Co-op company $(p<0.0001)$ in cooperating with suppliers to standardize packaging.

In Shell, the inputs are divided into two main groups; raw materials (base oils and additives) and Packaging material (bottles, packs, drums, caps, pallets, pails, stretch wrap and cartons). All these materials are recycled and reused. These inputs are discharged into main storage holding tanks (base oil and additives) and warehouses (packing material) to be used later on throughout the whole manufacturing cycle. The base oil and additives are blended with certain percentages according to the final product's bill of materials (BOM) and required a specification for each product. After blending, the mixed product is pumped through a system of pipelines that transfers it to the filling lines. The product is then dispensed in the designated packaging containers to be then transported to the finished products warehouse for storage until being shipped outside the facility to customers LOBP. It is notably to mention that using life cycle assessment in Co-op Company is under the responsibilities Petro Trade Company. Concerning replacing hazardous 
substances, Shell company is concerned with recycling both the used oil and packages, while the Co-op is concerned basically with recycling the used oil only.

\section{Reverse logistics}

The results of the extent of the firm practices of reverse logistics are shown in Table 4. The results of dealing with disposal indicated that Shell company had significantly higher extent as regards the firm practice of reverse logistics than the Co-op company ( $p<$ 0.0001). Regarding the processing of returned merchandise, the results showed that Shell company has significantly higher extent of the firm practice of reverse logistics than the Co-op company $(p<$ 0.00001 ). Finally, the analysis results revealed that Shell company had significantly higher extent of the firm practice of reverse logistics than the Co-op Company $(p<0.0001)$ in repackaging product.

Shell's SC is adopting the lean strategy as it is always working on minimizing if not eliminating the waste. This includes all types of daily wastes with the concentration on inventory reduction on both the raw materials side as well as the finished product side. There are lots of efforts exerted in this area especially qualifying six sigma professionals to be able to assist in the company's strategy and be even leaner according to [47]. On the contrary, Co-op company (and all local companies) are charged of collecting used oil from distributing companies. Thus, establishing Petro Trade Company to collect used oil from all resources to increase the amount of collected oil will be a significant recommendation besides obliging service stations to establish land tanks for collecting used oil.

Table 4. EXTENT OF THE FIRM Practices OF REVERSE LOGISTICS.

\begin{tabular}{|l|c|c|}
\hline Reverse Logistics & Shell & Co-op \\
\hline Dealing with Disposal & $66^{\star * *}$ & 33 \\
\hline Processing Returned Merchandise & $75^{\star * *}$ & 25 \\
\hline Repackaging Product & $75^{\star * *}$ & 0 \\
\hline
\end{tabular}

Source: Research Data (2019) by using Fisher's exact tes.

4. Operational performance with regards to implementation of GSCM practices

The results of operational performance with regards to implementation of GSCM practice are shown in Table 5. The result indicated that the quality at Shell company has significantly higher extent in green procurement practices than the Co-op company $(p<0.0001)$. Furthermore, the safety at Shell Company revealed significantly higher extent of the firm practice of green procurement than that of Co-op company $(p<0.00001)$. Additionally, the delivery at Shell company had significantly higher extent the firm practice green procurement than the Co-op Company $(p<0.0001)$. Finally, the flexibility at Shell company had a significantly higher extent the firm practice green procurement than that of the Co-op company $(p<$ 0.0001 ). Finally, as shown in the Table 5 , the overall effects of GSCM practices on operational performance reflected on quality, safety, delivery and flexibility.

The competency relies always to the delivery on time of their wide range of portfolio as well as providing several after-sales technical support services which made them currently the market leader lubricants' supplier for eight years in a row. Nevertheless, Shell is the highest spender on research and development reaching an annual spend of 1.3 billion dollars to be able to come up with the products that fulfill today's customers' needs. As mentioned above, the majorities of the raw materials supplied to the SC in Egypt as well as other countries are imported goods and have strict environmental specifications. Moreover, sometimes finished goods themselves are imported (or exported from other plants in the world) to satisfy a certain need in another operating unit. It is worth mentioning that planning is based on the historical statistical forecast of the products' range. In other words, based on the finished product forecast, the material requirement planning (MRP) tools are used to explore the bill of materials (BOM) and accordingly know the requirements from all BOM components. Based on the forecast as well, the company usually plans for all its capacities and requirements. Accordingly, a sourcing plan with the companies' suppliers is constructed to fulfill the requirements of the customers. The raw and packaging materials are then converted to the finished product during the manufacturing stage. After this step, the finished product is sent to the distribution center to and be arranged and then sent to customers. In case of any faulty delivery, the company accepts returns from customers as per the service level agreement with the customer. 
Table 5. OPERATIONAL PERFORMANCE WITH REGRADS TO IMPLEMENTATION OG GSCM PRACTICES.

\begin{tabular}{|c|c|c|}
\hline Impact & Shell Company & Co-op \\
\hline Quality & $75^{\star \star \star}$ & 25 \\
\hline Safety & $66^{\star \star *}$ & 33 \\
\hline Delivery & $75^{\star \star *}$ & 25 \\
\hline Flexibility & $75^{\star \star *}$ & 0 \\
\hline
\end{tabular}

Source: Research Data (2019) by using Fisher's exact tes.

\section{Discussion of theoretical and managerial} implications

According to [48], GSCM is increasing expanding enthusiasm among specialists and professionals of operations and SCM. The developing significance of GSCM is driven principally by the expanding crumbling of nature; that is, reducing crude material assets, flooding waste locales and expanding levels of contamination. Actually, the GSCM is a business esteem driver and not a cost focus [45];[17].

A successful way for SC managers to strengthen the reliability of SCs is to complete a benchmarking exercise to assess how well their SC is performing. In order to complete such an exercise, a benchmarking approach for GSC performance can help benchmark SCs based on their impact on the operational performance factors.

Based on the data collected and analyzed, Figure 4 presents the refined conceptual framework for GSCM practices for petrochemical companies in Egypt.

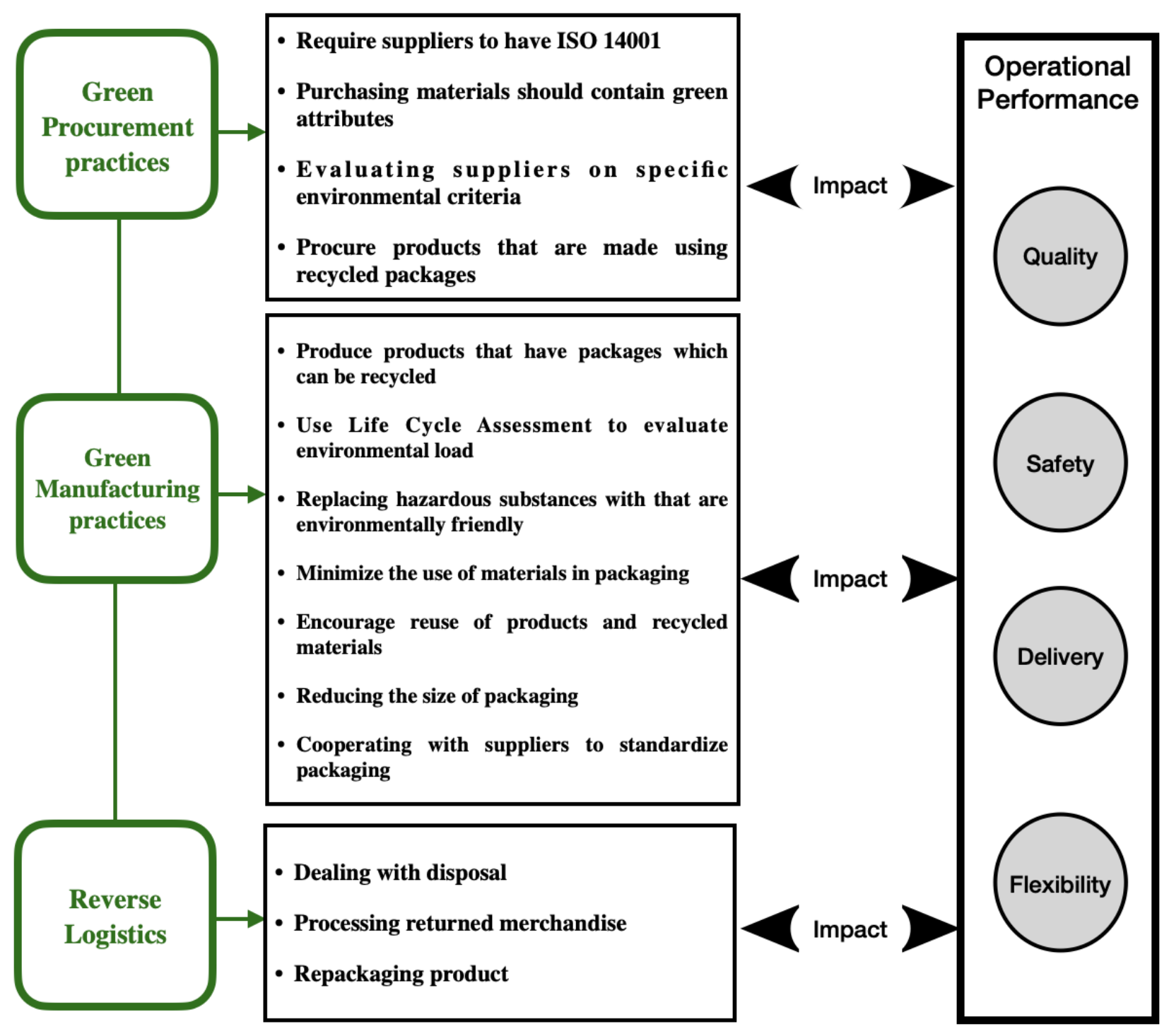

Fig. 4. Conceptual framework for GSCM practices for petrochemical companies in Egypt. Source: developed by the authors. 
The empirical results fulfilled the objectives of the study and generated adequate evidence for practitioners and decision makers to understand the various kinds of GSCM practices and to what extent the adopted practices influence the operational performance. Moreover, the research strongly supported the view that to green the environment requires collective responsibility and cross-functional cooperation for environmental improvements by the petrochemical's companies.

Likewise, this study specifies several empirical evidences for the impact of three dimensions of GSCM practices (green purchasing, green manufacturing, and reverse logistics) on four operational performance dimensions (quality, safety, delivery, and flexibility) and customer satisfaction. Based on the analysis of the comebacks collected from the respondents of the study, Shell Egypt has already begun to implement GSCM practices such as deliberating suppliers" ISO 14000 certification; purchasing materials that contain green attributes; evaluating the suppliers on specific environmental criteria; replacing hazardous substances with those that are environmentally friendly, etc. Consistent with the current literature, GSCM practices drives the entire chain stakeholders to deal effectively with environmental problems, from the beginning of product design, development, and production, to reach the end user [22]; [7] . Thus, these implications offer guidelines to petroleum and lubricant manufacturers to enhance their operational performance and customer satisfaction while employing GSCM practices throughout their entire SC.

\section{CONCLUSIONS AND RECOMMENDATIONS}

This study was carried out to determine the effect of GSC practices on operational performance using a benchmarking study between Shell Egypt and Co-op Petroleum Company working in the lubricant industry. The study had two objectives. The first was to determine the extent of GSC practices used by Shell and Co-op Petroleum Company in Egypt; the second objective was to establish the relationship between green SC management practices and operational performance of Shell and the Co-op Petroleum Company in Egypt. The study showed that Shell Egypt, which operates in the lubricant industry, appreciates the role of green supply chain practices. The company practices green procurement. Most practices are to ensure that suppliers comply with their environmental goals, purchase green materials, purchase energy-saving equipment, and other green manufacturing practices adopted by Shell. Furthermore, Shell also uses recycling and collaboration with suppliers to standardize packaging and then reduce package size. Shell has faced challenges in implementing green supply chain practices but has access to the tools and techniques needed to measure the performance of green supply chain management. This corresponds to the challenges identified by the Rider Center for Supply Chain Management (2008). The three independent variables of GSCM practices have clearly improved recycling and reuse opportunities, as well as improved operational performance and thus customer loyalty. As for the Co-op Petroleum Company, it is clear that they used raw materials and packaging materials that cannot be recycled and that are non-reusable, although the Co-op Company has realized the importance of GSCM practices. Environmental issues are not used in the selection criteria of suppliers because of the company's lack of appropriate technology, which is a major challenge. It also lacks the GSCM, which had a direct negative impact on customer loyalty.

Therefore, GSCM is an operational innovation that petrochemical firms may adopt to address environmental concerns, such as, complying with stringent environmental regulations, addressing the environmental concerns of their suppliers and customers, and to mitigating the environmental impact of their production and service activities. In the future, implementing a GSC will be even more important than it is today. Reasons for this are: Concentrating on more government legislation, growing awareness of environmental issues and motivating consumers to be more sustainable. Thus, greening the SC is not an alternative, it is becoming a norm.

The area of GSCM is relatively young and is still suffering from a shortage of information. This research will help to bring forth unknown information in the petroleum industry that will go a long way in facilitating further understanding of GSCM practices adoption. Future researchers will empirically test the relationships suggested in this paper in different companies to enable comparative studies. A larger sample would also allow detailed cross-sectoral comparisons which are not possible in the context of this study. To be efficient and effective in GSCM, collaboration among important stakeholders in the petroleum marketing firms supply chain must be 
strongly concerned. This study recommends the creation of awareness of the role of GSCM practices for the benefit of all the stakeholders and for sustainable economic and environment development.

\section{REFERENCES}

[1] Hsu, C.-W. and A.H. Hu, Green supply chain management in the electronic industry. International Journal of Environmental Science \& Technology, 2008. 5(2): p. 205-216.

[2] Rao, P. and D. Holt, Do green supply chains lead to competitiveness and economic performance? International journal of operations \& production management, 2005.

[3] Mumtaz, U., et al., Identifying the critical factors of green supply chain management: Environmental benefits in Pakistan. Science of the Total Environment, 2018. 640: p. 144-152.

[4] Montshiwa, A.L., Supply chain cooperation as a green supply chain management implementation strategy to achieve competitive advantages in natural disaster prone regions. Competitiveness Review: An International Business Journal, 2018.

[5] Sheu, J.-B., Y.-H. Chou, and C.-C. Hu, An integrated logistics operational model for greensupply chain management. Transportation Research Part E: Logistics and Transportation Review, 2005. 41(4): p. 287-313.

[6] Puckett, J. and T. Smith, Exporting harm: the high-tech trashing of Asia The Basel Action Network. Silicon Valley Toxics Coalition, Seattle, 2002.

[7] Zhu, Q., J. Sarkis, and K.-h. Lai, Institutionalbased antecedents and performance outcomes of internal and external green supply chain management practices. Journal of Purchasing and Supply Management, 2013. 19(2): p. 106117.

[8] Zhu, Q. and J. Sarkis, An inter-sectoral comparison of green supply chain management in China: drivers and practices. Journal of cleaner production, 2006. 14(5): p. 472-486.

[9] Olugu, E.U., et al., SUSTAINABLE SUPPLY
CHAIN MANAGEMENT IN MALAYSIAN SMES: PERSPECTIVES FROM PRACTITIONERS. Environmental Engineering \& Management Journal (EEMJ), 2017. 16(9).

[10] Bottani, E., et al., Economic and environmental assessment of different reverse logistics scenarios for food waste recovery. Sustainable Production and Consumption, 2019. 20: p. 289303.

[11] Sycara, K., et al., CADET: a case-based synthesis tool for engineering design. International journal of expert systems, 1991. 4(2): p. 157-188.

[12] Beamon, B.M., Supply chain design and analysis:: Models and methods. International journal of production economics, 1998. 55(3): p. 281-294.

[13] Kumar, R. and R. Chandrakar, Overview of green supply chain management: operation and environmental impact at different stages of the supply chain. International Journal of Engineering and Advanced Technology, 2012. 1(3): p. 1-6.

[14] Vachon, S. and R.D. Klassen, Supply chain management and environmental technologies: the role of integration. International journal of production research, 2007. 45(2): p. 401-423.

[15] Schmidt, C.G., K. Foerstl, and B. Schaltenbrand, The supply chain position paradox: green practices and firm performance. Journal of Supply Chain Management, 2017. 53(1): p. 3-25.

[16] Luthra, S., et al., An integrated framework for sustainable supplier selection and evaluation in supply chains. Journal of Cleaner Production, 2017. 140: p. 1686-1698.

[17] Vanalle, R.M., et al., Green supply chain management: An investigation of pressures, practices, and performance within the Brazilian automotive supply chain. Journal of cleaner production, 2017. 151: p. 250-259.

[18] Green Jr, K.W., D. Whitten, and R.A. Inman, Aligning marketing strategies throughout the supply chain to enhance performance. Industrial 
Marketing Management, 2012. 41(6): p. 10081018.

[19] Foo, M.Y., et al., Green purchasing capabilities, practices and institutional pressure. Management of Environmental Quality: An International Journal, 2019.

[20] Zhang, L., et al., The influence of greenwashing perception on green purchasing intentions: The mediating role of green word-of-mouth and moderating role of green concern. Journal of Cleaner Production, 2018. 187: p. 740-750.

[21] Ma, P., et al., Pricing decisions for substitutable products with green manufacturing in a competitive supply chain. Journal of Cleaner Production, 2018. 183: p. 618-640.

[22] Karimi, B., et al., Multi-objective multi-facility green manufacturing closed-loop supply chain under uncertain environment. Assembly Automation, 2019.

[23] Bai, C. and J. Sarkis, Integrating and extending data and decision tools for sustainable third-party reverse logistics provider selection. Computers \& Operations Research, 2019. 110: p. 188-207.

[24] Carter, C.R. and D.S. Rogers, A framework of sustainable supply chain management: moving toward new theory. International journal of physical distribution \& logistics management, 2008. 38(5): p. 360-387.

[25] Chen, C.-C., Incorporating green purchasing into the frame of ISO 14000. Journal of Cleaner Production, 2005. 13(9): p. 927-933.

[26] Sezen, B. and S.Y. Cankaya, Effects of green manufacturing and eco-innovation on sustainability performance. Procedia-Social and Behavioral Sciences, 2013. 99: p. 154-163.

[27] Dubey, R., A. Gunasekaran, and S.S. Ali, Exploring the relationship between leadership, operational practices, institutional pressures and environmental performance: A framework for green supply chain. International Journal of Production Economics, 2015. 160: p. 120-132.

[28] Fernández, I. and T. Kekäle, The influence of modularity and industry clockspeed on reverse logistics strategy: implications for the purchasing function. Journal of Purchasing and Supply Management, 2005. 11(4): p. 193-205.

[29] Agrawal, S. and R.K. Singh, Analyzing disposition decisions for sustainable reverse logistics: Triple Bottom Line approach. Resources, Conservation and Recycling, 2019. 150: p. 104448.

[30] Bohas, A. and N. Poussing, An empirical exploration of the role of strategic and responsive corporate social responsibility in the adoption of different Green IT strategies. Journal of cleaner Production, 2016. 122: p. 240-251.

[31] Sarkis, J., Q. Zhu, and K.-h. Lai, An organizational theoretic review of green supply chain management literature. International journal of production economics, 2011. 130(1): $p$. 1-15.

[32] Canning, L. and S. Hanmer-Lloyd, Modelling the adaptation process in interactive business relationships. Journal of Business \& Industrial Marketing, 2002.

[33] Tate, W.L., L.M. Ellram, and J.F. Kirchoff, Corporate social responsibility reports: a thematic analysis related to supply chain management. Journal of supply chain management, 2010. 46(1): p. 19-44.

[34] Singh, A. and A. Trivedi, Sustainable green supply chain management: trends and current practices. Competitiveness Review, 2016.

[35] Sarkis, J. and Y. Dou, Green supply chain management: A concise introduction. 2017: Routledge.

[36] $\mathrm{Wu}, \mathrm{A}$. and T. Li, Gaining sustainable development by green supply chain innovation: Perspectives of specific investments and stakeholder engagement. Business Strategy and the Environment, 2020. 29(3): p. 962-975.

[37] Liu, Z., V. Jayaraman, and Y. Luo, The unbalanced indirect effects of task characteristics on performance in professional service outsourcing. International Journal of Production 
Economics, 2017. 193: p. 281-293.

[38] Yang, J., et al., The influence of environmental management practices and supply chain integration on technological innovation performance-Evidence from China's manufacturing industry. Sustainability, 2015. 7(11): p. 15342-15361.

[39] Famiyeh, S., et al., Green supply chain management initiatives and operational competitive performance. Benchmarking: An International Journal, 2018.

[40] Andersen, B. and R.C. Camp, Current position and future development of benchmarking. The TQM Magazine, 1995.

[41] Simatupang, T.M. and R. Sridharan, A benchmarking scheme for supply chain collaboration. Benchmarking: An International Journal, 2004.

[42] Sueyoshi, T. and M. Goto, Data envelopment analysis for environmental assessment: Comparison between public and private ownership in petroleum industry. European journal of operational research, 2012. 216(3): $p$. 668-678.
[43] Nunes, B. and D. Bennett, Green operations initiatives in the automotive industry: An environmental reports analysis and benchmarking study. Benchmarking: An International Journal, 2010. 17(3): p. 396-420.

[44] Sharif, A.M., Benchmarking performance management systems. Benchmarking: An International Journal, 2002.

[45] Glasser, B. and A.L. Strauss, The development of grounded theory. Chicago, IL: Alden, 1967.

[46] Cox, M.K. and C.H. Key, Post hoc pair-wise comparisons for the chi-square test of homogeneity of proportions. Educational and Psychological Measurement, 1993. 53(4): p. 951-962.

[47] Eckes, G., Six Sigma team dynamics. The Elusive Key to Project, John Wiley\& Sons Inc., New Jersey, 2003.

[48] Srivastava, S.K., Green supply-chain management: a state-of-the-art literature review. International journal of management reviews, 2007. 9(1): p. 53-80. 